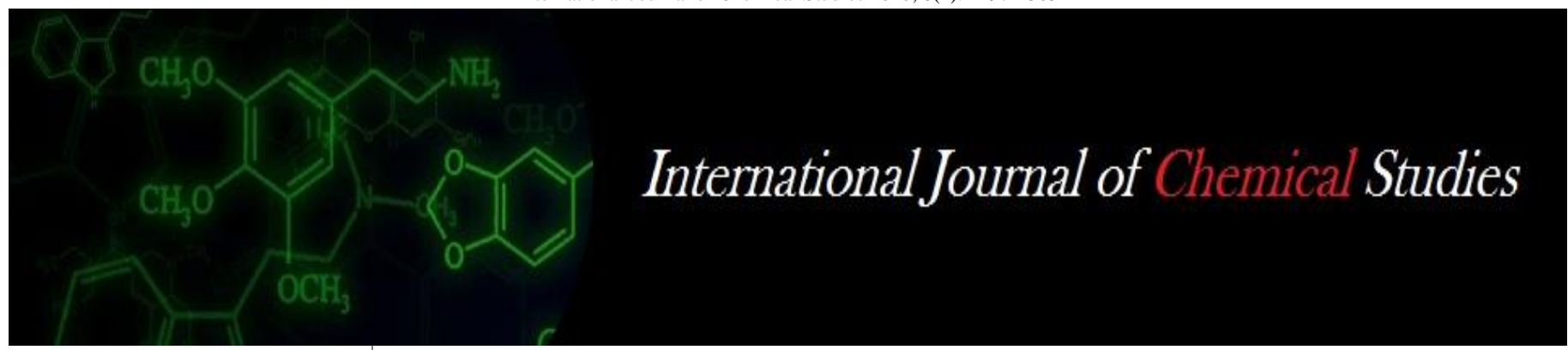

P-ISSN: 2349-8528

E-ISSN: 2321-4902

www.chemijournal.com

IJCS 2020; 8(4): 2297-2303

(C) 2020 IJCS

Received: 17-05-2020

Accepted: 19-06-2020

\section{R Rajeswari}

Assistant Professor, Departmen

of Soil Science and Agricultural

Chemistry, Tamil Nadu

Agricultural University,

Coimbatore, Tamil Nadu, India

\section{S Natarajan}

Tamil Nadu Agricultural

University, Coimbatore,

Tamil Nadu, India

\section{MR Latha}

Tamil Nadu Agricultural

University, Coimbatore,

Tamil Nadu, India

M Umadevi

Tamil Nadu Agricultural

University, Coimbatore,

Tamil Nadu, India

\section{Leninraja}

Tamil Nadu Agricultura

University, Coimbatore,

Tamil Nadu, India

\section{S Thenmozhi}

Tamil Nadu Agricultura

University, Coimbatore,

Tamil Nadu, India

\section{Corresponding Author:}

\section{R Rajeswari}

Assistant Professor, Department

of Soil Science and Agricultural

Chemistry, Tamil Nadu

Agricultural University,

Coimbatore, Tamil Nadu, India

\section{Carbon sequestration in relation to soil morphological, physical and chemical properties- A review}

\author{
R Rajeswari, S Natarajan, MR Latha, M Umadevi, D Leninraja and S \\ Thenmozhi
}

DOI: https://doi.org/10.22271/chemi.2020.v8.i4z.9978

\begin{abstract}
The greenhouse effect has been of great concern and has led to several studies on the quality, kind, distribution and behaviour of SOC. Global warming and its effect on soils in terms of SOC management has led to several quantitative estimates for global carbon content in the soils. Restoration of soil quality through soil organic carbon (SOC) management has remained the major concern for tropical soils. Important factors controlling SOC levels include climate, hydrology, parent material, soil fertility, biological activity, vegetation patterns and land use. SOC is sensitive to impact of human activities viz., deforestation, biomass burning, land use changes and environmental pollution. The contribution of SOC on physical, chemical and biological properties of soils in sustaining their productivity are being appreciated since the dawn of human civilization. The comprehensive knowledge on influence of soil properties, bio climates, and land use on Soil Organic Carbon (SOC) stocks forms an essential prerequisite in future land resource management programmes.
\end{abstract}

Keywords: Soil organic carbon (SOC), soil properties, bioclimates, land use, land management

\section{Introduction}

Carbon sequestration refers to the storage of carbon in a stable solid form. It occurs through direct or indirect fixation of atmospheric $\mathrm{CO}_{2}$. Direct soil carbon sequestration occurs by inorganic chemical reactions that convert $\mathrm{CO}_{2}$ into soil inorganic compounds such as calcium and magnesium carbonates. Indirect plant carbon sequestration occurs as plant photosynthesize atmospheric $\mathrm{CO}_{2}$ into plant biomass. Subsequently, some of this plant biomass is indirectly sequestered as soil organic carbon during decomposition process.

SOC is vital for ecosystem function having a major influence on soil structure, water holding capacity, cation exchange capacity and the soils ability to form complexes with metal ions and store nutrients (Van Keulen, 2001) ${ }^{[56]}$. The first comprehensive study of organic carbon status in Indian soils was conducted by Jenny and Raychaudhuri (1960) ${ }^{[28]}$. Their study confirmed the effects of climate on carbon reserves in the soils. However this estimate was based on a hypothesis of enhancement of organic carbon level, judging by success stories of afforestation programmes on certain unproductive soils. The soil carbon sequestration potential of 39.3 to 49.3Tg $\mathrm{C} / \mathrm{Yr}$ (mean of 43.3Tg $\mathrm{C} / \mathrm{Yr}$ ) can be significant towards reducing the net emission from fossil fuel combustion and decreasing the rate of enrichment of $\mathrm{CO}_{2}$.

Further, there is an additional potential of carbon sequestration in biomass especially by forest and other biota. This potential is considerable in terms of the negotiation under the provision of Clean Development Mechanisms under IPCC and for trading carbon in the national and international markets.

Excluding carbonate rocks, soils represent the largest terrestrial stock of $\mathrm{C}$, holding approximately $1500 \times 10^{15} \mathrm{~g} \mathrm{C}$ (Batjes, 1996) ${ }^{[2]}$. This is approximately twice the amount held in the terrestrial vegetation (Smith, 2004) ${ }^{[51]}$. In most soils (except calcareous soils) the majority of this C is held in the form of SOC (Batjes and Sombrock, 1997) ${ }^{[3]}$. Appropriate knowledge about SOC, factors influencing SOC and management of soils to increase SOC levels increase the productivity and sustainability of agricultural ecosystems and vice-versa (Cole et al., 1997) [19]. 
(In this review, an overview is presented on relationship of carbon sequestration with morphological, physical and chemical properties of soil. And also Influence of bioclimates, land use systems and management practices on carbon sequestering potential of soil have been explored.

\section{Morphological properties and their influence in sequestration of Soil Organic Carbon (SOC) and Soil Inorganic Carbon (SIC)}

The study on soil morphology provides a scope to know more about the external features and structures of soil body in a profile which may be the manifestations of pedogenic processes in soils. Generally these properties are colour, texture, structure, horizonation, consistence, mottles, roots, coarse fragments, other features such as concretions, depth and width of cracks, presence of slickensides and reaction.

\subsection{Soil colour vis-à-vis SOC and SIC}

According to Simonson (1993) ${ }^{[45]}$ the colour of the soil depends on the content of organic matter and ferric oxides, the latter being more or less hydrated. Thicker the organic matter and ferric oxide, coating the soil grains, the darker is the soil. Vijay Kumar et al. (1996) ${ }^{[58]}$ stated that vertisols of Northern Telangana zone of Andhra Pradesh have been found to vary from dark gray to dark brown in colour. Black soils were dark in colour. The reason for dark colour was due to presence of titaniferous magnetite and soluble humus.

Tiwary et al. (1996) ${ }^{[55]}$ reported that red soils of Bihar, developed on different parent rocks were red to reddish brown and yellowish brown in colour. The variation in the intensity of redness within pedons could be due to the integrated effect of organic matter, $\mathrm{Fe}_{2} \mathrm{O}_{3}, \mathrm{MnO}_{2}, \mathrm{TiO}_{2}$ and clay content under existing redox environment. Walia and Chamuah (1996) [59] studied Inceptisols of Arunachal hills and reported that colour of ' $\mathrm{A}$ ' horizon is dark reddish brown in foot hills, dark brown in medium and high hills, brown in low hill soils. Such colour variations may be due to differences in organic matter and oxides of iron content of soils.

Bhattacharyya et al. (2007a) ${ }^{[13]}$ carried out the study in semiarid tropical part of India, to find the relation between carbon sequestration capacity of soil with their morphological properties. For this study, a total of 28 Benchmark (BM) spots were selected which included 52 pedon sites. The Nabibagh soils are darker (10 YR 3/2) under high management (HM) than the soils under farmers management (FM) (10 YR 3.5/2 to $10 \mathrm{YR} 4 / 2)$. This is also reflected by higher SOC content in HM than FM. Darker colour (10 YR 3/2) in Boripani surface soils also matches with relatively higher soil organic matter (9-10 $\left.\mathrm{g} \mathrm{kg}^{-1}\right)$. Although such observations indicate a strong degree of correlation between soil colour and SOC, such interpretations may be accepted based on large number of observations (Bhattacharjee, 1997) ${ }^{[5]}$.

Mahapatra et al. (2000) ${ }^{[31]}$ carried out the study in subhumid eco-system of Kashmir region and reported that soils have wide range of colour values from 2 to 4 , chromas 2 to 4 with mostly common hue of $10 \mathrm{YR}$. The surface horizons are darker than the sub soil suggesting high organic matter content in the surface layer.

\subsection{Roots vis-à-vis SOC and SIC}

Fresh and decayed roots of crops and trees identified in a soil profile do not contribute for SOC determined by Walkley and Black method until and unless they are humified. Higher root concentration leads to release of greater amount of root exudates. These exudates in turn dissolve $\mathrm{CaCO}_{3}$ present in soil, which help in better Ca nutrition in plants as well as developing a better soil structure, enhancing aeration and hydraulic conductivity. This process again brings better soil environment for crop growth and biological activities. It therefore, appears that concentration of roots either in surface or throughout the depth of the pedon has a role in modifying soil structure and other physical properties to enhance organic carbon sequestration and retard the sequestration of inorganic carbon (Bhattacharyya et al., 2004) ${ }^{[10]}$.

A search of the literature published during the last decade suggests, however, that deliberate rehabilitation of agricultural land with native prairie and grassland vegetation can greatly enhance soil $\mathrm{C}$ accumulation potentially offering a temporary means to help, curtail atmospheric $\mathrm{CO}_{2}$ build up during the next several decades. Sequestered $\mathrm{C}$ via prairie restoration efforts in degraded agricultural soils is attributable to a higher allocation of photosynthate ( $>50$ per cent) below ground to a dense, fibrous root system, a reduction in decomposition rates (Brye and Kucharik, 2003) ${ }^{[17]}$.

Bhattacharyya et al. (2007a) ${ }^{[13]}$ reported that, Nabibagh soils of Bopal, Madhya Pradesh under farmer's management has very fine and fine roots. Boripani soils of Nagpur, Maharashtra under forest show many fine, medium and coarse roots. In the Kheri soils of Jabalpur, Madhya Pradesh under high management fine roots are limited to surface horizon only. This could be due to the continuous cultivation of paddy - wheat for a considerable period of time.

\subsection{Coarse fragments, nodules and effervescence vis-à-vis SOC and SIC}

Recent investigations of forests indicate that coarse fractions contain substantial carbon and consideration of only the fine fraction would substantially underestimate the whole soil carbon pool. Cromack et al. (1999) ${ }^{[21]}$ reported that $<2 \mathrm{~mm}$ fraction contains only 63 per cent of whole soil carbon and remaining 37 per cent was observed in $>2 \mathrm{~mm}$ fraction in a Coastal Oregon forest. Bauhus et al. (2002) ${ }^{[4]}$ determined 53 to 80 per cent of whole soil carbon in $<2 \mathrm{~mm}$ fraction and 20 -47 per cent at whole soil carbon in $>2 \mathrm{~mm}$ fractions in three Australian forests. Harrison et al. (2003) ${ }^{[26]}$ found 37 per cent of whole soil carbon in $<2 \mathrm{~mm}$ fraction, 63 per cent of whole soil carbon in $>2 \mathrm{~mm}$ fraction at one western Washington site. In another site of Western Washington they found 97 per cent of whole soil carbon in $<2 \mathrm{~mm}$ fraction, 3 per cent of whole soil carbon in $>2 \mathrm{~mm}$ fraction.

Bhattacharyya et al. (2007a) ${ }^{[13]}$ reported that in relatively high rainfall zone (sub-humid moist) amount of coarse fragments (i.e. $\mathrm{CaCO}_{3}$ ) content and the degree of effervescence are compatible. In sub-humid (dry) and semiarid (dry) climate both the coarse fragments and $\mathrm{CaCO}_{3}$ content increase. The degree of effervescence also increases from wet to dry climate in terms of SOC content, the general trend is that more coarse fragments show less SOC content. Earlier such inverse relation of SOC and SIC $\left(\mathrm{CaCO}_{3}\right)$ has been reported in Indian soils (Bhattacharyya et al., 2000). For the red soils the coarse fragments consist of gravels of parent rock and they do not contain $\mathrm{CaCO}_{3}$.

\subsection{Other morphological features of the soils vis-à-vis SOC and SIC}

Other features like slickensides, cracks, gilgai microrelief in the black soils are indirectly related with SOC and SIC. Bhattacharyya et al. (2007a) ${ }^{[13]}$ observed the soils in Central India contain low SOC $(<0.5$ per cent in the surface $)$ and it decreases with depth. SIC and SOC have an inverse relation 
in terms of their occurrence in soil profile. SOC in most of the soils range between 0.3-0.85 cutting across the bioclimatic system. The $\mathrm{CaCO}_{3}$ content in the slickensided horizons also shows an increasing trend from sub-humid moist to arid climate.

Relative proportion of SOC is more in the soil depth occurring above the slickensides. The SOC content is 26 per cent, 60 per cent, 28 per cent, 57 per cent and 27 per cent more in the soil depth above slickensides (than that below the depth of slickensides) in subhumid (moist), subhumid (dry), semi-arid (moist), semi-arid (dry) and arid bioclimate, respectively. The SIC content at this soil depth (above slickensides) is less than the lower depth (below slickensides) by 8 per cent, 8 per cent, 16 per cent, 25 per cent and 5 per cent in sub-humid (moist), sub-humid (dry), semi-arid (moist), semi-arid (dry) and arid bioclimate, respectively. The soil depth above the slickensides with 26-60 per cent more SOC and 5-25 per cent less SIC $(43-56 \mathrm{~cm})$ may be considered relatively safe zone as compared to the soil depth below the slickensides.

Singh et al. (2000) ${ }^{[48]}$ carried out the study in old alluvial soils of Sone Basin and observed slickensides in Andour, Bhagwanpur and Belthari soils at a depth of $150 \mathrm{~cm}, 100 \mathrm{~cm}$ and $40-55 \mathrm{~cm}$ respectively. The organic carbon content in these soils ranged between $0.6-3.7 \mathrm{~g} \mathrm{~kg}^{-1}$. Dutta et al. (2000) stated that variation in SOC content of soils in different land forms is due to the varied nature of parent materials which influences organic carbon storage through its effect on texture in addition to micro-relief and soil drainage that contribute greatly to organic carbon storage in soils. Higher SIC content indirectly shows development of subsoil sodicity which is a sign of natural chemical degradation of soils (Pal et al., 2000; Srivastava et al., 2002; Bhattacharyya et al., 2000) ${ }^{[36,52,12] .}$

\section{Physical properties and their influence on sequestration} of SOC and SIC

\subsection{Particle size distribution in soils vis-à-vis carbon} sequestration

McVay and Rice (2002) ${ }^{[34]}$ reported that soils vary in the amount of soil organic carbon contain, ranging from less than 1 per cent in many sandy soils to greater than 20 per cent in soils found in wetlands or bogs. Kansas soils have a native soil organic carbon content ranging from 1 to 4 per cent. Soil texture influences the soil micro environment and Soil Organic Matter (SOM) mineralization in several ways. As clay content increases, soil surface area and organic matter stabilization potential increase. This stabilized SOM can have a turnover time ranging from 10 to 1000 years (Mercax et al., 1985) ${ }^{[35] .}$

Broersma and Lavkulich (1980) ${ }^{[15]}$ reported that 24 to 48 per cent of the organic matter in selected soils of Canada was associated with the clay fraction and 40 to 60 per cent was associated with the fine silt fraction. Six et al. (2002) [50] stated that stabilization capacity is dictated by soil silt and clay content and the surface area and reactivity of mineral soil particles in increasing soil aggregation. Soil clay content indirectly affects soil $\mathrm{C}$ storage by occluding organic materials, making them inaccessible to degrading organisms and their enzymes.

Bhattacharyya et al. (2007b) ${ }^{[14]}$ carried out the study in semiarid tropical part of India and reported that SOC is positively correlated with texture while SIC shows a negative correlation. When the relation with SOC and three different combination of substrate was compared (0-30 cm depth) highest correlation was found in SOC vs fine clay $(<0.2 \mu \mathrm{m})$ followed by SOC vs total clay $(<2 \mu \mathrm{m})$. McDaniel and Munn (1985) concluded the study in grass land soils of Montana and Wyoming and reported that correlations of organic $\mathrm{C}$ with sand and clay contents were highest for mesic mollisols and mesic aridisols and decreased as temperature regimes became colder. Sand/clay ratio was significantly correlated with organic $\mathrm{C}$ in mesic soils only and therefore may not be useful in distinguishing between Typic and Borollic sub groups of frigid Aridisols.

\subsection{Bulk desity vis-a-vis carbon sequestration}

Bulk density of black soils decreases as SOC content increase in first $30 \mathrm{~cm}$ depth in soil. For red soils, bulk density is low in the subhumid moist bioclimatic system. These soils are rich in organic matter and are under forest. These landscapes at the upper part support Mollisols which are in association with red ((alfisols) and black soils (vertisols) (Bhattacharyya et al., 2006) ${ }^{[11]}$. Organic carbon sequestration in soils will decrease the bulk density and this SOC built-up may be more pronounced in the higher rainfall area. In case of inorganic carbon sequestration, though the formation of powdery lime will increase bulk density; with time this powdery lime will form $\mathrm{CaCO}_{3}$ nodules to decrease bulk density (Bhattacharyya et al., 2005) ${ }^{[6]}$.

Sharma et al. (1994) ${ }^{[43]}$ reported that higher bulk density of soils is due to their coarse texture and in some cases the presence of calcium carbonate and low organic carbon content. Jagadish prasad et al. (2001) ${ }^{[27]}$ reported that bulk density of orange growing soils of Nagpur district of Maharastra ranged from 1.52 to $1.72 \mathrm{Mg} \mathrm{m}^{-3}$. Bulk density has significant positive relationship with clay and water retention. and negatively correlated with organic carbon content (2.1 to $\left.9.9 \mathrm{~g} \mathrm{~kg}^{-1}\right)$. Maji et al. (2005) ${ }^{[32]}$ reported that bulk density of the soils over basaltic terrain in sub-humid tropics of Central India varies from 1.33 to $1.79 \mathrm{Mg} \mathrm{m}^{-3}$. Variation in bulk density of these swell-shrink soil may be attributed to higher organic matter content, moisture content and high content of expanding type of clay minerals present.

Surface soils are less compact probably due to high amount of organic matter and plant root concentration (Coughlan et al., 1986) ${ }^{[20]}$. Thangasamy et al. (2005) ${ }^{[54]}$ conducted a study at Sivagiri micro-watershed of Chittoor district in Andhra Pradesh and reported that bulk density of these soils varied from 1.32 to $1.90 \mathrm{Mg} \mathrm{m}^{-3}$ and increased with depth which might be due to more compaction of finer particles in deeper layers caused by overhead weight of the surface soils. Low bulk density values of surface soils could be attributed due to high organic matter content.

\subsection{Hydraulic conductivity vis-a-vis carbon sequestrtion.}

Hydraulic conductivity measures the drainage of soils. At the beginning of wet season these soils show good drainage due to the presence of cracks. With the passage of time drainage is impeded especially in the subsurface horizons due to compaction. It has been found that soils showing better drainage contain more SOC. This is because organic matter increases soil drainage which is reflected by high hydraulic conductivity (Bhattacharyya and Pal, 2003) ${ }^{[7]}$.

Balpande et al. (1996) ${ }^{[1]}$ reported that organic matter can dissolve native $\mathrm{CaCO}_{3}$ and decrease the soil $\mathrm{pH}$ which in turn decreases the ESP and increase the $\mathrm{HC}$ of soils. In the wetter bioclimatic zones, $\mathrm{CaCO}_{3}$ present as powdery lime is dissolved due to decrease in $\mathrm{pH}$ effected by the increase in SOC. This happens by C-transfer model (Bhattacharyya et al., 2004) ${ }^{[10]}$. Total amount of $\mathrm{CaCO}_{3}$ cannot be used as an 
indicator for soil drainage, without the knowledge of proportion of non pedogenic carbonates (NPC) and pedogenic carbonates (PC) (Bhattacharyya et al., 2007b) ${ }^{[14]}$.

The soils of Sivagiri micro-watershed of Chittoor district in Andhra Pradesh are poorly drained to excessively drained. $\mathrm{CaCO}_{3}$ content in poorly drained soil is $4.1-8.3 \mathrm{~g} \mathrm{~kg}^{-1}$ but in excessively drained soil it is $4.2-108.1 \mathrm{~g} \mathrm{~kg}^{-1}$. This shows there is a direct correlation between drainage and $\mathrm{CaCO}_{3}$ content (Thangasamy et al., 2005) ${ }^{[54]}$.

\section{Chemical properties and their influence in sequestration of SOC and SIC}

\section{1. $\mathrm{pH}$ vis-a-vis SOC and SIC}

Increase in aridity increase the $\mathrm{pH}$ due to precipitation of $\mathrm{CaCO}_{3}$ and increases the ESP. Therefore, it is expected that an increase in rainfall or decrease in aridity retards the formation of $\mathrm{CaCO}_{3}$ and also decreases soil $\mathrm{pH}$ (Pal et al., 2000) ${ }^{[36]}$. Bhattacharyya et al, (2007b) ${ }^{[14]}$ conducted a study in semi-arid tropical part of India and reported that the relationship between $\mathrm{pH}$ and SOC is inverse in the vertisols of all the bioclimatic zones except soils under arid climate. The soils of higher elevation over basaltic terrain in sub-humid tropic of central India are acidic (6.0-6.5) in reaction. But the soils of lower topography of the same region are alkaline in reaction (7.7-8.3). The higher topography is more acidic due to organic carbon content $\left(5.1-9.7 \mathrm{~g} \mathrm{~kg}^{-1}\right)$ and no $\mathrm{CaCO}_{3}$ accumulation (Maji et al., 2005) ${ }^{[32]}$.

Nearly, 76 per cent area of sub-humid ecosystem of Kashmir region are generally slightly acidic to neutral, 2 per cent area is moderately acidic and 22 per cent area is slightly alkaline. The acidic nature is generally associated with high level of organic matter and leaching of bases due to sloping landscape and fluvial actions whereas higher $\mathrm{pH}$ is due to calcareousness (Mahapatra et al., 2000) [31]. Sharma et al. (2004) ${ }^{[44]}$ conducted a study in Neogal watershed of NorthWest Himalayas and recorded higher organic carbon and lower soil $\mathrm{pH}$ values in surface as compared to subsurface horizons. These results can be attributed to leaf fall/decay, soil forming factors (vegetation and parent material, low in bases, heavy rainfall, low temperature and sloppy topography) Generally, there is a negative relationship between SOC and $\mathrm{pH}$. Degradation of SOC is carried out by diverse groups of microorganisms, soil fungi being the most dominant among them. In high rainfall regions, the base forming minerals are leached out leading to soil acidity. The soil acidity in turn, favours the proliferation of saprophytic fungi that accounts for higher net accumulation of SOC (Pal and Shrupali, 2006) ${ }^{[37]}$.

\subsection{ESP vis-a-vis SOC and SIC}

Bhattacharyya et al. (2007b) ${ }^{[14]}$ conducted a study in semiarid tropical part of India, and reported that, in all the bioclimates, there is an increasing trend of SOC with decrease in ESP. The increase of SOC decreases soil $\mathrm{pH}$, which helps to release $\mathrm{Ca}^{2+}$ in the system by dissolving $\mathrm{CaCO}_{3}$. This results in decreased ESP. The ESP values show an increasing trend with SIC value in all the bioclimatic zones. It is well known that increase in SIC increases the ESP of a soil system. This may be due to the relative contribution of pedogenic carbonates towards SIC, as pedogenic carbonates are directly proportional to ESP and also $\mathrm{Ca}^{2+}$ in the exchange complex is preferentially released to precipitate as $\mathrm{CaCO}_{3}$ thereby increasing the relative concentration of $\mathrm{Na}^{+}$in the exchange complex.

\section{Influence of bioclimates on SOC and SIC}

The soils of arid and semi-arid region may contain two to five times more SIC than SOC in the top soil layer (Sahrawat, 2003) ${ }^{[42]}$. The hill soils of west Bengal have high organic matter content. The organic matter content of high altitude soils is higher than the low altitude soils. The high organic matter content of the soils is mainly due to their low temperature and heavy rainfall (Lahiri and Chakravarti, 1995) [53]. Singh and Datta (1988) [47] carried out the study in Mizoram and reported that organic carbon and readily oxidizable organic matter contents increase with the increasing elevation. The values are high in the surface horizons but then decrease sharply down the profile in the subsurface. The organic carbon and readily oxidizable organic matter in the surface soils from 70 to $1835 \mathrm{~m}$ altitude have positive correlation with the altitude.

Higher rainfall influences overall biomass production in soils of Rajasthan, Cooler climate and higher clays are responsible for high organic carbon density in great groups of Alfisols, Vertisols and Inceptisols than Aridisols for both 0-25 and 0$100 \mathrm{~cm}$ soils (Singh et al., 2005) ${ }^{[49]}$. Pal and Shurpali (2006) [37] conducted a study to know the variation in soil organic carbon as influenced by climate and found, a significant and positive relationship between SOC and rainfall and combined effect of rainfall and temperature controlled its accumulation. In low rainfall zones, SOC content decreased with increasing temperatures, but in high rainfall zones, the reverse was true. Organic carbon increased with precipitation and clay content decreased with temperature. Carbon losses due to cultivation increased with precipitation and the relative carbon losses are lowest in clay soils (Bruke et al., 1989) ${ }^{[16]}$. Bhattacharyya et al. (2007) ${ }^{[8]}$ conducted a study in semi-arid tropical part of India and pointed out that rainfall has an overriding influence over other climatic parameters in sequestering organic carbon in soils. In this region, SOC values of black soils in first $30 \mathrm{~cm}$ depth show concentrations of $0.83,0.80,0.60,0.63$ and 0.59 per cent for semi-arid (moist), semi-arid (dry), sub-humid (moist), sub-humid (dry) and arid bioclimatic systems respectively. For the red soils, the SOC follows the trend like sub-humid (moist) 1.35 per cent $>$ semi-arid (dry) 0.84 per cent $>$ semi-arid (moist) 0.74 per cent

\section{Influence of land use systems on SOC and SIC sequestration}

Forest plays a major role in the global carbon cycle. Between 62 per cent and 78 per cent of the global terrestrial $\mathrm{C}$ is sequestered in forest. Forest soil tends to accumulate more $\mathrm{C}$ than does soil under agriculture, because the carbon turns over more slowly (Guggenberger et al., 1994) ${ }^{[25]}$. Soil that formed under forests tend to accumulate high levels of soil organic carbon near the surface and have lower carbon levels in the subsoil. This layering of soil is primarily due to the accumulation of leaf litter and decaying wood from limbs and trees that accumulate at the soil surface (Mc Vay and Rice, 2002) ${ }^{[34]}$.

Deforestration followed by $25 \mathrm{yr}$ of pasture caused a net loss 1.5 $\mathrm{Mg} \mathrm{C} \mathrm{ha}^{-1}$ for the Oxic Humitropept in Atlantic zone of Costa Rica. Due to strong stabilization of SOC in Al-organic matter complexes in soils of volcanic origin and the continuous cover of grass land, the decline in SOC after forest clearing was less than visually reported (Veldkamp, 1994) [57]. Olsson and Ardo (2002) ${ }^{[30]}$ investigated the potential for increasing soil carbon content in semi-arid agro ecosystems in the Sudan and found that increasing fallow periods will result in increased soil carbon content and converting marginal agricultural areas to rangeland will 
restore the carbon levels to 80 per cent of the natural savannah carbon levels in 100 years.

Rehabilitation of agricultural land with native prairie and grassland vegetation can greatly enhance soil $\mathrm{C}$ accumulation (Brye and Kucharik, 2003) ${ }^{[17]}$. Global C sequestration rates on land converted from agricultural production to grassland was $33.2 \mathrm{~g} \mathrm{~cm}^{-2} \mathrm{yr}^{-1}$ (Post and Kwon, 2000) ${ }^{[38]}$. Bhattacharyya et al. (2007) ${ }^{[8]}$ selected five land use systems in semi-arid tropical part of India and reported that, higher concentration of organic carbon was under forest system (1.44 per cent), followed by permanent fallow (1.42 per cent), horticultural system ( 0.80 per cent). Agricultural system ( 0.70 per cent) and wasteland ( 0.47 per cent). The sequestration of inorganic carbon on the other hand, was found to be highest in horticultural system and agricultural system ( 0.80 per cent), and followed by wasteland ( 0.70 per cent) and forest system (0.16 per cent).

\section{Influence of Management on SOC and SIC sequestration}

Conservation tillage over the past few decades has indicated that soil organic matter can be maintained or improved (Franzluebbers, 2002) ${ }^{[23]}$. Manipulation of cropping systems using appropriate rotations can also enhance soil organic matter (Katsvairo et al., 2002) ${ }^{\text {[29] }}$. Observations of Ryan (1998) ${ }^{[41]}$ indicated that some legumes such as Medic and Vetch had produced higher levels of organic matter than continuous cereal cropping and fallow. Medic has an extensive root system, which contributes organic matter in the root zone than merely leaf fall on the soil surface.

Long-term experiments in Australia showed that soil under long-term pasture (1918-1986) contained $11.5 \times 10^{9} \mathrm{~g} \mathrm{ha}^{-1}$ more organic carbon than unfertilized cropped plots (Ridley et al., 1990) [40]. Cadisch et al. (1998) ${ }^{[18]}$ reported that the introduction of improved pastures increased SOC at the rate of 230 to $3300 \mathrm{Kg} \mathrm{C} \mathrm{ha}{ }^{-1} \mathrm{yr}^{-1}$ in tropics. Singh and Singh (1993) ${ }^{[46]}$ reported that rising trees on alkali soils of Karnal increased SOC from 0.12 per cent to a maximum of 0.58 per cent. In irrigated areas of dry sub-humid and per humid climate addition of a green manure crop preferably a legume in a sequence or addition of farmyard manure or organic manure or green leaf maturing and crop sequencing with legume should be a part of strategy to maintain organic carbon to permissible higher level (Pratap Narain, 2001) ${ }^{[45]}$.

\section{Conclusion}

Intensive cultivation during the green and post-green revolution era of Indian agriculture has resulted loss in soil carbon amidst widespread degradation in natural resources and nutrients. The vision 2020 document of the Government of India (GOI, 2002) envisages a production level of rice and wheat as 207 and 173 million tonnes after giving due consideration to biophysical factors restricting crop production. The reports of decline in SOC and the consequent adverse impacts on productivity require sound resource base. This necessitates taking stock of soil carbon in relation to soil properties at different places. This provides an essential tool and benchmark for monitoring the quality of management interventions to sustain the agricultural productivity of the country.

\section{References}

1. Balpande SS, Deshpande SB, Pal DK. Factors and processor of soil degradation in vertisols of the pure valley, Maharashtra, India. Land degradation and Development. 1996; 7:313-324.

2. Batjes NH. Total carbon and nitrogen in the soils of the world. Eur. J Soil Sci. 1996; 47:151-163.

3. Batjes NH, Sombrock WG. Possibilities for carbon sequestration in tropical and sub-tropical soils. Glop. Chang Biol. 1997; 3(2):161-173.

4. Bauhus J, Khanna PK, Hopmans P, Weston C. Is soil carbon a useful indicator of sustainable forest soil management? A case study from native eucalypt forests of south eastern Australia. Ecol Manage. 2002; 171:5974.

5. Bhattacharjee SC. 'Introduction of Pedology Vol. 1 Soil genesis" Oxford and IBH publishing Co. Pvt. Ltd., New Delhi, 1997.

6. Bhattacharyya T, Pal DK, Chandran P, Ray SK. Land use, clay mineral type and organic carbon content in two Millisols-Alfisols-Vertisols catenary sequences of topical India. Clay Research. 2005; 24:105-122.

7. Bhattacharyya T, Pal DK. Role of soil colloids in carbon accumulation in soils; a view. Rice Wheat Information Sheet. 2003; 47:6.

8. Bhattacharyya T, Pal DK, Easter M, Baties NH, Milne E, Gajbhiye KS et al. Modelled soil organic Carbon stocks and changes in the Indo-Gangetic plains, India from 1980 to 2030. Agriculture, Ecosystems and Environment, 2007, 1-11.

9. Bhattacharyya T, Pal DK, Velayutham M, Chandran P, Mandal C. Total carbon stock in Indian soils: Issues, priorities and Management. In: Land resource management for food and environment security (ICLRM), Soil Conservation Society of India, New Delhi, 2000, 1-46.

10. Bhattacharyya T, Pal DK, Chandran P, Mandal C, Ray SK, Gupta RK, Gajbhiye KS. Managing soil carbon stocks in the Indo-gangetic plains, India, Rice-Wheat Consortium for the Indo-Gangetic plains, New Delhi110-012, India, 2004, 44.

11. Bhattacharyya T, Pal DK, Lal S, Chandran P, Ray SK. Formation and persistence of Mollisols on zeolitic Deccan Basalt of humid tropical India. Geoderma. 2006; 136:609-620.

12. Bhattacharyya T, Pal DK, Mandal C, Velayutham M. Organic carbon stock in Indian soils and their geographical distribution. Current science. 2000; 79(5):655-660.

13. Bhattacharyya T, Chandra P, Ray SK, Pal DK, Venugopalan MV, Mandal C et al. Carbon sequestration of red and black soils of semi-arid tropical part of India. I Influence of morphological properties. Agropedology. 2007a; 17(1):1-15.

14. Bhattacharyya T, Chandran P, Ray SK, Pal DK, Venugobalan MV et al. Carbon sequestration in red and black soil of semi-arid tropical part of India: II Influence of physical and chemical properties of soil. Agropedology. 2007b; 17(1):16-25.

15. Broersma K, Lavkulich LM. organicmatter distribution with particle size in surface horizons of some sombric soils in Vancouver Island. Can. J Soil Sci. 1980; 60:583-586.

16. Bruke IC, Yonker CM, Parton WJ, Cole CV, Flach K, Schimel DS. Texture, climate and cultivation effects on soil organicmatter content in U.S. Grassland soil. Soil Sci. Soc. Am. J. 1989; 53:800-805. 
17. Brye KR, Kucharik CJ. Carbon sequestration in two prairie topochrono sequences on contrasting soils in southern Wisconsin. Am. Midl. Nar. 2003; 149:90-103.

18. Cadisch G, Re Oliveria OC, Cantarutti R, Carvalho E, Urquiaga S. In: carbon and nutrient dynamics in natural and Agricultural tropical Ecosystem. (Bergstroem, L and H. Kirchwanu Ed). AB International, Wallingford, U.K, 1998, 47-69.

19. Cole CV, Duxbury J, Frenecy J, Heinemeyer O, Minami $\mathrm{K}$, Mosier A et al. Global estimates of potential mitigation of greenhouse gas emissions by agriculture. Nutr. Cycl. Agroecosyst. 1997; 49(1-3):221-228.

20. Coughlan KJ, McGarry D, Smith GD. The physical and mechanical characterization of vertisols. In: First Regional seminar on management of vertisols under semi-arid conditions. IBSRAM proceeding number 6 Nairobi, Kenya, 1986, 89-106.

21. Cromack K, Miller Jr RE, Helgerson OT, Smith RB, Anderson HW. Soil carbon and nutrients in a coastal Oregon Douglas-Fir plantation with red alder. Soil Sci. Soc. Am. J. 1999; 63:232-239.

22. Dutta D, Sah KD, Reddy RS, Anil Kumar KS, Arti Koyal. Soil organic carbon storage in different landforms of South Deccan Plateau of Andhra pradesh. J Indian Soc. Soil Sci. 2000; 48(3):447-450.

23. Franzluebbers AJ. Soil organic matter stratification ratio as an indicator of soil quality. Soil till Research. 2002; 60:95-106.

24. Govt. of India-Planning Commission Report, Report of the committee on India vision, New Delhi, 2002.

25. Guggenberger G, Christensen BT, Zech W. Land-use effects on the composition of organic matter in particlesize separates of soils. I lignin and carbohydrate signature. European Journal of soil science. 1994; 45:449-458.

26. Harrison RB, Adams AB, Licata C, Flaming B, Wagoner GI, Carpenter P, Vance ED. Quantifying deep soil and Coarse, soil fractions. Avoiding sampling bios. Soil Sci. Soc. Am. J. 2003; 67:1602-1606.

27. Jagadish Prasad MS, Nagaraju Rajeev Srivastara S, Ray SK, Chandran P. Characteristics and classification of some orange growing soil in Nagpur district of Maharashtra. J Indian Soc. Soil Sci. 2001; 49(4):735-739.

28. Jenny H, Raychaudhuri SP. Effect of climate and cultivation on nitrogen and organic matter receiver in Indian soils, ICAR, New Delhi. India, 1960, 126.

29. Katsvairo TW, Cox WJ, Van HM. Tillage and rotation effects on soil physical characteristics. Agron. J. 2002; 92:299-304.

30. Olsson L, Ardo J. Soil carbon sequestration in degraded semi-arid agro ecosystem perils and potentials. Ambio. 2002; 31(6):471-477.

31. Mahapatra SK, Walia CS, Sidhu GS, Rana KPC, Lal T. Characterization and classification of the soils of different physiographic units in the sub humid eco system of Kashmir region. Indian Soc. Soil Sci. 2000; 48(3):572-577.

32. Maji AK, Oby Reddy GP, Thayalan S, Walke WJ. Characterization and classification of land farms and soils over basaltic terrain in sub-humid tropics of central India. J Indian Soc Soil Sci. 2005; 53(2) :154-162.

33. Mc Daniel PA, Munn LC. Effect of temperature on organic carbon texture relationships in Mollisols and Aridisols. Soil Sci. Soc. Am. J. 1985; 49:1486-1489.
34. Mc Vay, Charles W. Rice. Soil Organic Carbon and the Global Carbon Cycle. Kansas State University, 2002.

35. Mercax R, Den Hartog A, Van Veen JA. Turn-over of root derived material and related microbial biomass formation in soils of different texture. Soil. Biol. Biochem. 1985; 17:565-569.

36. Pal DK, Dasog GS, Vadivelu S, Ahuja RL, Bhattacharyya T. Secondary calcium carbonate in soils of semi-arid region of India. In: Global climate change and redogenic carbonates. (Ed. Lal R, Kimble JM, Eswaran H, Stewart BA). (CRC Press Boca Raton, Washington), 2000, 149-185.

37. Pal SS, Shurpali NJ. Variation in soil organic carbon as influenced by climate under different cropping system in India. J Indian Soc Soil Sci. 2006; 54(3):294-299.

38. Post WM, Kwon KC. Soil carbon sequestration and land use changes processes and potential. Global change Biol. 2000; 6:317-327.

39. Pratap Narain. Strategies of carbon sequestrating on degraded soils. J Indian Soc of soil Sci. 2001; 49(4):634646.

40. Ridley AM, Slattery WJ, Helyar KR, Cowling A. Aust. J Expl. Agric. 1990; 30:539.

41. Ryan J. changes in organic carbon in long-term rotation and tillage trials in northern Syria. In : Lal, R. Kimble, J. Follet, R., Stewart, B.A (Ed.), Management of carbon sequestration in soil and Advance soil science RC press, Boca Raton, FL, USA, 1998, 285-295.

42. Sahrawat KL. Importance of Inorganic carbon in sequencing carbon in soils of the dry regions. Current science. 2003; 84(7):864-865.

43. Sharma SP, Sharma PD, Singh SP, Minhas RS. Characterization of Soan river valley soils in lower sioraliks of Himachal Pradesh-Ii. Piedmont and flood plain soils. J Indian Soc Soil Science. 1994; 42:105-110.

44. Sharma VK, Sharma PD, Sharma SP, Acharya CL, Sood RK. Characterization of cultivated soil of Neogal watershed in North-West. Himalayas and their suitability for major crops. J Indian Soc Soil Sci. 2004; 52(1):63-68.

45. Simonson RW. Soil colour standards and terms for field use history of their development. In: Soil colour : SSSA special publication No.31 (Ed). Bingham JM, Ciolkosz EJ. Soil Science Society of America, Madison, Wisconsin, USA, 1993, 1-20.

46. Singh G, Singh NT. In: Mesquite for Vegetation of Saltaffected Soils (Research Bulletin No. 18). Central Soil Salinity Research Institute, Karnal, 1993.

47. Singh OP, Datta B. Organic carbon and nitrogen status of some soils of Mizoram occurring at different altitudes. J Indian Soc Soil Sci. 1988; 36:414-420.

48. Singh RN, Singh RNP, Divakar DPS. Characterization of old Alluvial soils of one Basin. J Indian Soc Soil Science. 2000; 48(2):352-357.

49. Singh SK, Singh RS, Shyampura RL, Pratap Narain. Organic and in organic carbon stock in soils of Rajasthan. J Indian Soc soil science. 2005; 53(3):281-287.

50. Six J, Conant RT, Paul EA, Paustian K. Stabilization mechanisms of soil organicmatter : Implications for Csaturation of Soils. Plant Soil. 2002; 241:155-176.

51. Smith P. Soils as carbon sinks-the global context. Soil Use Manage. 2004; 20:212-218.

52. Srivastava P, Pal DK, Bhattacharyya T. Significance of the formation of calcium carbonate minerals in the pedogenesis and management of cracking clay soil 
(vertisols) of India. Clay and Clay Minerals. 2002; 50:111-126.

53. Lahiti TC, Chakravarthi SK. Distribution and nature of organic matter in some hill soil of west Bengal at various altitudes in the Eastern Himalayan Region. J India Soc. Soil Science. 1995; 43(3):464-466.

54. Thangasamy A, Naidu MVS, Ramanathan N, Raghara Reddy C. Characterization, classification and evaluation of soil resources in Sivagiri micro-water shed of chittoor district in Andhra Pradesh for sustainable land are planning. J Indian Soc. Soil Sci. 2005; 53(1):11-21.

55. Tiwary JR, Singh ID, Mishra BB, Mall J. Characterization of red soils derived from five different parent rocks in Bihar. Agropedology. 1996; 6(2):13-20.

56. Van Keulen H. (Tropical) Soil organic matter modeling: Problems and prospects. Nutr. Cycl. Agroecosyst. 2001; 61(1/2):33-39.

57. Veldkamp E. Organic carbon turnover in three tropical soils under pasture after deforestation. Soil Sci. Soc. Am. J. 1994; 58:175-180.

58. Vijayakumar TM, Suryanarayana Reddy, Gopalakrishna V. Vertical distribution of micronutrient cations in some soil profiles of Northern Telengana of Andhra Pradesh. J Indian Soc. Soil Sci. 1996; 44(2):328-330.

59. Walia CS, Chamuah GS. Characterization of some Inceptisols of Arunachal Hills. J India Soc. Soil Sci. 1996; 44(1):179-182. 